\title{
Tuberous Sclerosis Complex with rare associated findings in the gastrointestinal system: a case report and review of the literature
}

Larissa Brussa Reis ${ }^{1,2+}$, Daniele Konzen ${ }^{3,4+}$, Cristina Brinckmann Oliveira Netto ${ }^{5}$, Pedro Moacir Braghirolli Braghini ${ }^{6}$, Gabriel Prolla ${ }^{4}$ and Patricia Ashton-Prolla ${ }^{1,2,5^{*}}$ (D)

\begin{abstract}
Background: Tuberous Sclerosis Complex (TSC) is a complex and heterogeneous genetic disease that has wellestablished clinical diagnostic criteria. These criteria do not include gastrointestinal tumors.

Case presentation: We report a 45-year-old patient with a clinical and molecular diagnosis of TSC and a family history of cancer, presenting two rare associated findings: gastrointestinal polyposis and pancreatic neuroendocrine tumor. This patient was subjected to a genetic test with 80 cancer predisposing genes. The genetic panel revealed the presence of a large pathogenic deletion in the TSC2 gene, covering exons 2 to 16 and including the initiation codon. No changes were identified in the colorectal cancer and colorectal polyposis genes.

Discussion and conclusions: We describe a case of TSC that presented tumors of the gastro intestinal tract that are commonly unrelated to the disease. The patient described here emphasizes the importance of considering polyposis of the gastrointestinal tract and low grade neuroendocrine tumor as part of the TSC syndromic phenotype.
\end{abstract}

Keywords: Tuberous sclerosis complex, Adenomatous colonic, Rectal polyposis, Pancreatic neuroendocrine tumor, Case report

\section{Background}

Tuberous Sclerosis Complex (TSC) is a genetic disorder with multiorgan involvement, a broad phenotype with inter and intra-familiar variability and well-established clinical diagnostic criteria (Table 1) [1-4]. The incidence of TSC is approximately 1 in 6000-10,000 live births, and in Europe its prevalence has been estimated to be

\footnotetext{
* Correspondence: pprolla@hcpa.edu.br

${ }^{+}$Larissa Brussa Reis and Daniele Konzen contributed equally to this work.

'Laboratório de Medicina Genômica - Centro de Pesquisa Experimental -

Hospital de Clinicas de Porto Alegre (HCPA), Porto Alegre, Rio Grande do Sul,

Brazil

2Programa de Pós-graduação em Genética e Biologia Molecular,

Universidade Federal do Rio Grande do Sul (UFRGS), Porto Alegre, Rio Grande do Sul, Brazil

Full list of author information is available at the end of the article
}

8.8/100,000 [5]. Germline pathogenic variants in TSC1 and TSC2 are identified in $75-90 \%$ of patients with the clinical diagnosis and at least $60 \%$ of TSC patients do not have a family history of the disease and are considered sporadic [6].

In this report, we describe a patient with the clinical and molecular diagnosis of TSC presenting with two rare associated findings: gastrointestinal polyposis and a pancreatic neuroendocrine tumor. A review of the literature on the subject is provided.

\section{Case presentation}

The patient, a 45-year-old male, was referred for genetic assessment due to clinical findings suggestive of

\section{$\triangle B M C$}

(c) The Author(s). 2020 Open Access This article is licensed under a Creative Commons Attribution 4.0 International License, which permits use, sharing, adaptation, distribution and reproduction in any medium or format, as long as you give appropriate credit to the original author(s) and the source, provide a link to the Creative Commons licence, and indicate if changes were made. The images or other third party material in this article are included in the article's Creative Commons licence, unless indicated otherwise in a credit line to the material. If material is not included in the article's Creative Commons licence and your intended use is not permitted by statutory regulation or exceeds the permitted use, you will need to obtain permission directly from the copyright holder. To view a copy of this licence, visit http://creativecommons.org/licenses/by/4.0/. The Creative Commons Public Domain Dedication waiver (http://creativecommons.org/publicdomain/zero/1.0/) applies to the data made available in this article, unless otherwise stated in a credit line to the data. 
Table 1 Criteria for the clinical diagnosis of TSC [1]

\begin{tabular}{lll}
\hline Criteria & Description & $\begin{array}{l}\text { Observed in } \\
\text { the proband }\end{array}$ \\
\hline Major & Facial angiofibroma & $\checkmark$ \\
& Ungueal/peri-ungueal fibroma & \\
& Hypomelanotic macules & \\
& Subependymal nodules & \\
& Cortical tubers & $\checkmark$ \\
& Subependymal giant cell astrocitoma (SEGA) & \\
& Multiple nodular retinal hamartomas & \\
& Cardiac rhabdomyoma & \\
& Renal angiomyolipoma \\
& Lynphangiomyomatosis \\
& Multiple dental enamel macules \\
& Rectal polyps \\
& Osseous cysts \\
& Abnormal migration tracts of the White matter \\
Gengival fibromas & \\
Minon-renal hamartomas & \\
Multiple renal cysts & "Confetti" skin lesions
\end{tabular}

Definitive TSC: Two major criteria or one major and two minor criteria;. Probable TSC: One major and one minor criterion; Possible TSC: One major and two minor criteria

Tuberous Sclerosis Complex (TSC) and polyposis of the gastrointestinal tract. Past medical history included symptoms such as significant seizures since infancy, mild cognitive impairment and adult-onset psychiatric symptoms. These symptoms prompted investigation with a brain magnetic resonance imaging (MRI), which showed subependymal nodules and cortical tubers, two major diagnostic criteria of TSC. Physical examination revealed facial angiofibroma but no additional cutaneous abnormalities were observed. Ophthalmologic, cardiac e pulmonary evaluations did not reveal presence of retinal hamartomas, cardiac rhabdomyomas or pulmonary lymphangioleiomyomatosis. Abdominal computed tomography (CT) scans showed an expansive lesion with heterogeneous enhancement, located in the lower pole of the right kidney, measuring $5.5 \mathrm{~cm} \times 4.0 \mathrm{~cm}$ which was later confirmed as a renal angiomyolipoma, another classical sign of TSC. Multiple nodular lesions with arterial enhancement were identified in the liver, the largest one measuring $7.0 \times 5.0 \mathrm{~cm}$ with features suggestive of secondary implants of unknown origin. In addition, abdominal imaging also showed an expansive lesion in the pancreatic body, with heterogenous enhancement, involving the splenic artery and measuring approximately $6.0 \times 4.0 \mathrm{~cm}$. In addition, the patient also had a long history of diarrhea and underwent colonoscopy and upper gastrointestinal endoscopy, revealing presence of more than 50 gastric, colonic and rectal polypoid formations $(2 \mathrm{~mm}$ to $5 \mathrm{~mm}$ ).

Family history of cancer was significant for presence of 2 relatives with central nervous system tumors (father and brother diagnosed at ages 62 and 57 years, respectively). Eight additional cancer unaffected siblings were reported. There was also no report of any other family member with clinical features of Tuberous Sclerosis Complex or other genetic conditions. Considering the clinical features of TSC and polyposis of the digestive tract, germline genetic testing was proposed with a next generation sequencing panel validated for large rearrangement screening including 80 cancer predisposition genes in a commercial laboratory. Genes in the panel included: $A L K, A P C, A T M$, AXIN2, BAP1, BARD1, BLM, BMPR1A, BRCA1, BRCA2, BRIP1, CASR, CDC73, CDH1, CDK4, CDKN1B, CDKN1C, CDKN2A (p14ARF), CDKN2A (p16INK4a), CEBPA, CHEK2, DICER1, DIS3L2, EPCAM, FH, FLCN, GATA2, GPC3, GREM1, HRAS, KIT, MAX, MEN1, MET, MLH1, MSH2, MSH6, MUTYH, NBN, NF1, NF2, PALB2, PDGF RA, PHOX2B, PMS2, POLD1, POLE, POT1, PRKAR1A, PTCH1, PTEN, RAD50, RAD51C, RAD51D, RB1, RECQ L4, RET, RUNX1, SDHAF2, SDHB, SDHC, SDHD, SMAD4, SMARCA4, SMARCB1, SMARCE1, STK11, SUFU, TERC, TERT, TMEM127, TP53, TSC1, TSC2, VHL, WRN, WT1 genes. The patient died due to complications of the disease a few months after genetic evaluation. Informed consent to publish this case report was obtained post-mortem from his spouse.

Regarding pathology of the tumors, the haematoxylin and eosin stain (HE) performed in lesion of the right kidney revealed round cell renal tumor with typical morphology (Fig. 1a). The liver lesions were biopsied, showing a histologic pattern suggestive of a low-grade neuroendocrine tumor (NET) (Fig. 1c and e). Biopsies of the pancreatic lesion diagnosed a low-grade neuroendocrine pancreatic tumor (PanNET). Based on the major phenotypic criteria identified in the patient, the clinical diagnosis of TSC with a rare manifestation (PanNET) was established. Partial polypectomies were performed resecting three polyps from the gastric body, two polyps from the right colon and four polyps from the rectum. Histologic examinations of the gastric and colonic/rectal polyps revealed fundic gland polyps and tubular adenomas with low-grade dysplasia, respectively (Fig. 2). Immunohistochemistry (IHC) was performed in the biopsy of the right kidney lesion and demonstrated positive expression of melanoma antigen (Melan A) (Fig. 1b), melanosomal glycoprotein gp100 antigen (HMB45) and smooth muscle actin antigen. The lesions in the liver were confirmed by $\mathrm{IHC}$, showing positivity for multiple citokeratins antigens $(40,48,50$ e 50,6 kDa), chromogranin A antigen (CGA) (Fig. 1d), and synaptophysin (Sinapto) (Fig. 1f). 


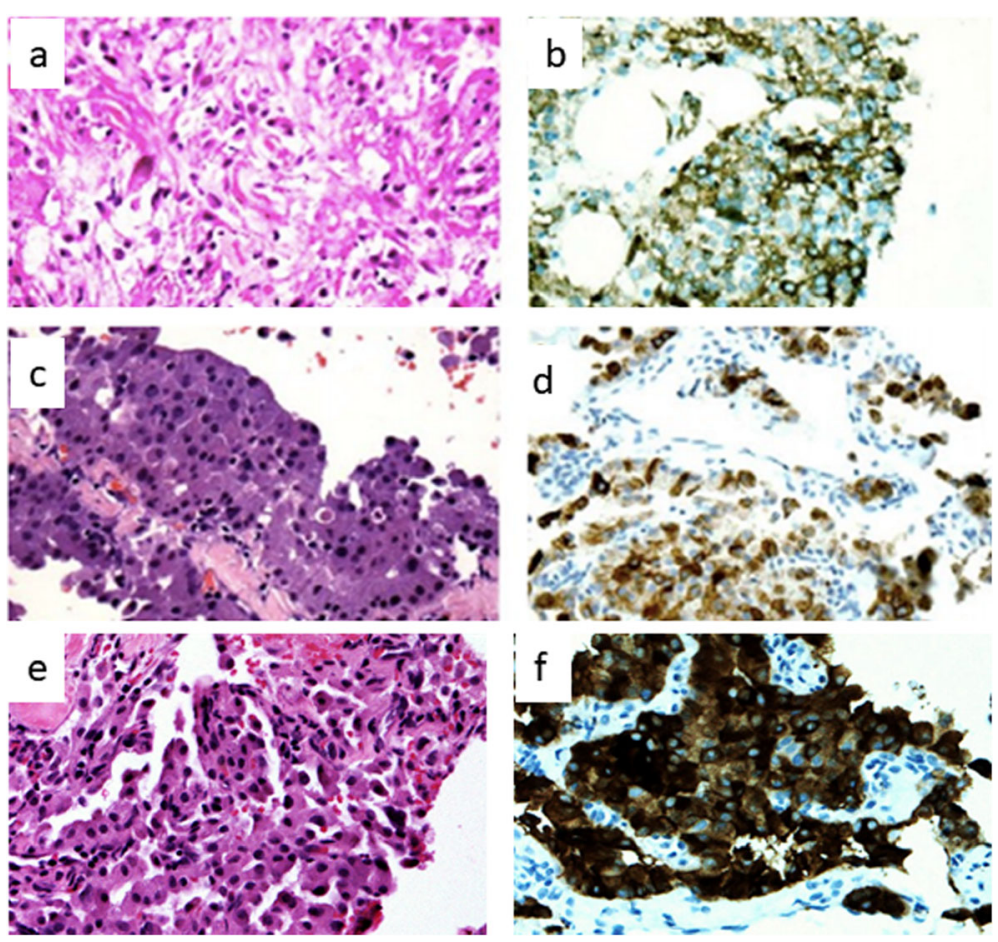

Fig. 1 Histologic and immunohistochemistry analyses of the renal and hepatic lesions identified in the proband. a and $\mathbf{b}$ : Kidney biopsy: round cell neoplasia of the kidney (renal angiomyolipoma). a) HE: haematoxylin and eosin stain, b) Melan A: melanoma antigen. c, d, e and f: Liver biopsy (low grade endocrine neoplasia). c) HE: haematoxylin and eosin stain, d) CGA: chromogranin A antigen, e) HE: haematoxylin and eosin stain, f) Sinapto: synaptophysin (HE and IHC, 200x)

Germline genetic testing revealed presence of a large pathogenic deletion in TSC2 gene encompassing exons 2 to 16 and including the initiation codon. No alterations in colorectal cancer/colorectal polyposis genes (APC, AXINS2, BMPR1A, CDH1, CHEK2, EPCAM, GREM1, MLH1, MSH2, MSH3, MSH6, MUTYH, NTHL1, PMS2, POLD1, POLE, POLE, PTEN, SMAD4, STK11, TP53) were identified.

\section{Discussion and conclusions}

TSC is an autosomal dominant disease associated with cancer predisposition and multisystemic involvement mainly due to hyperactivation of the mTOR pathway, secondary to loss of function mutations in TSC1 and TSC2 [7]. Approximately $15 \%$ of the pathogenic variants identified in TSC2 and $8 \%$ of those identified in TSC1 are large gene rearrangements (LGR) [8], and therefore, genotyping using a methodology that allows LGR detection is important in a diagnostic workup. Although criteria for clinical diagnosis of TSC are well established, expressivity is highly variable, even within families with multiple carriers of the same pathogenic variant and simplex cases with de novo mutations are not
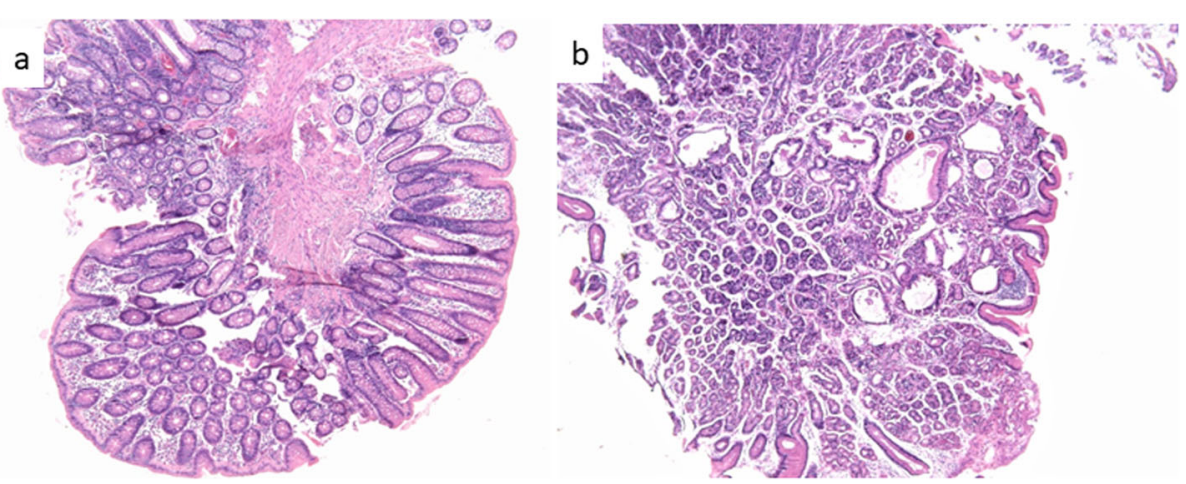

Fig. 2 Tubular adenoma and Fundic gland polyp (HE). Panel a: tubular adenomas. Panel b: fundic gland polyps (HE, 200x) 
uncommon reaching up to $86 \%$ in some cohorts [9]. The recent, increased access to multigene panel testing to investigate suspected hereditary cancer has resulted in molecular diagnosis of individuals without the classic clinical criteria or apparently "sporadic" tumors or isolated clinical features of the disease.

In this report, we describe a patient fulfilling criteria for the clinical diagnosis of TSC, such as cortical tubers, facial angiofibroma and renal angiomyolipoma (Table 1 and Fig. 1a and b) carrying a previously described large TSC2 rearrangement with two uncommon clinical manifestations of the disease: gastrointestinal adenomatous polyposis and a metastatic pancreatic neuroendocrine tumor. The occurrence of numerous colonic and rectal polyps, characterized in this patient as tubular adenomas, is a symptom associated with gastrointestinal polyposis and colorectal cancer syndromes, such as Familial adenomatous polyposis (FAP), a rare autosomal, dominant hereditary disease [10]. FAP is caused by a germline mutation in the $A P C$ gene [11]. Besides FAP, other syndromes could be associated, including mismatch repair deficiency (biallelic $M L H 1, M S H 2, M S H 6$, $P M S 2$ gene mutations), polymerase proofreadingassociated polyposis (POLD1, POLE genes), juvenile polyposis (SMAD4, BMPR1A genes) and MUTYH-associated polyposis [12]. Sequence changes and exonic deletions/duplications were evaluated in all of these associated genes and negative results exclude these syndromes in this patient.

The heterozygous TSC2 exon 2-16 deletion identified is also known as deletion of exons 1-15 in the literature. Truncating variants including gross deletions in TSC2 are known to be pathogenic. The $5^{\prime}$ end of the deletion remained undetermined as it was beyond the assayed region and the 3' boundary was probably within intron 16 of the TSC 2 gene. This deletion is expected to result in complete removal of the TSC1 binding domain (T1BD) the N-terminus of the TSC2 protein in one of the alleles. This domain is critical for TSC1-TSC2 interaction (formation of TSC complex) and abnormal or absent TSC complex results in TSC2 ubiquitination and degradation. This in turn eliminates inhibition of the conversion of Rheb-GTP which accumulates and directly activates the mTORC1 pathway [13, 14].

Three previous reports describe TSC patients carrying the same germline TSC2 exon 2-16 (a.k.a. exon 1-15) deletion [15-17]. However, according to the information available, none of them presented the uncommon clinical features reported here (neuroendocrine tumors or gastrointestinal polyps) (Tables 2 and 3); although it is possible that due to their ages, these phenotypes would not yet be identifiable. Interestingly, Mortaji et al., 2018 described an adult TSC patient who presented both, a pancreatic NET and gastrointestinal (GI) polyps. But different from the case presented here, they were hamartomatous/inflammatory polyps [40]. Although rectal polyps are included as a minor clinical diagnostic criterion for TSC, there is no mention to polyps in other portions of the GI tract and the vast majority of polyps described in TSC patients are hamartomatous [19, 43]. Gastric fundic polyps (FGPs) are considered hamartomas and tuberin protein (codified by TSC2 gene) seems to play an important role in pathogenesis of sporadic FGPs by deregulation of cell proliferation. The altered cellular localization of tuberin interrupts its interaction with hamartin protein (codified by TSC1) preventing the formation of TSC complex that regulates mTORC1 pathway, responsible for cell proliferation and protein synthesis signaling pathways. In addition, altered cellular localization of tuberin may preclude its negative regulation of gene transcription mediated by tuberinassociated proteins glucocorticoid receptor (GCR) [44]. We identified only one case report of an adolescent TSC patient with tubular adenomatous polyps of the GI tract. The report by Digoy et al. (2000), and the case reported here, presented with a high number of GI tract polyps (unlikely somatic in origin) and a negative comprehensive evaluation of known polyposis genes, reinforce that GI polyposis with different histologies is likely part of the TSC phenotype and

Table 2 Previous reports of Gl tract polyposis in TSC patients

\begin{tabular}{|c|c|c|c|c|}
\hline Reference & Age & TSC features & GI tract alterations & Mutant gene $^{a}$ \\
\hline [18] & 17 yo female & $\begin{array}{l}\text { Mental retardation, brain astrocytoma, } \\
\text { facial angiofibroma, hypomelanotic } \\
\text { macules, renal angiomyolipoma }\end{array}$ & $\begin{array}{l}\text { Rectal adenocarcinoma and multiple } \\
(>50) \text { tubular adenomas }\end{array}$ & NA \\
\hline [19] & 42 yo female & $\begin{array}{l}\text { Seizures, renal and liver angiofibromas, } \\
\text { multiple subependymal calcifications of } \\
\text { the brain, lymphangioleiomyomatosis of } \\
\text { the lungs, cerebromalacia }\end{array}$ & Multiple gastric (fundic) hamartomas & NA \\
\hline [20] & 51 yo female & $\begin{array}{l}\text { Epilepsy, mild cognitive impairment, } \\
\text { ungueal fibromas. }\end{array}$ & $\begin{array}{l}\text { More than } 50 \text { sessile polyps of small size } \\
\text { scattered through the left colon and rectum }\end{array}$ & $\begin{array}{l}\text { TSC1 } \\
\text { c.1257delC } \\
\text { (p.Arg420Glyfs*20) }\end{array}$ \\
\hline
\end{tabular}


Table 3 Previous reports of neuroendocrine tumors in individuals with a clinical or clinical and molecular diagnosis of TSC

\begin{tabular}{lll}
\hline Reference & Summary & Mutant \\
\hline & Pituitary NET & NA \\
{$[21]$} & Case report: 12 yo male with a GH-oma and acromegalic gigantismo. & NA \\
{$[22]$} & Case report: 25 yo female with hyperprolactinaemia, amenorrhoea and galactorrhoea after delivery of 3rd child. & NA \\
{$[23]$} & Case report: 32 yo male with an ACTH-oma and Cushingoid features. & NA \\
{$[24]$} & Case report: 13.5 yo male with an ACTH-oma, short stature, abnormal distribution of fat tissue and rounded &
\end{tabular}

\section{Parathyroid NET}

[25] Case report: 20 yo female with parathyroid hyperplasia, and on autopsy multiple endocrine adenomatosis affecting, in addition to the parathyroid, the pituitary (a non-functioning pituitary adenoma), adrenals and pancreas (islet cell tumour).

[26] Case report: 14 yo female with a parathyroid adenoma, anorexia, occasional nausea and vomiting, polydipsia, polyuria, constipation and generalised osteoporosis

[27] Case report: 15 yo male with a parathyroid adenoma and acute pancreatitis

\section{Rectal NET}

[28] Case report: 18 yo female with Proteus syndrome and TSC, subcortical tubers, developmental delay, seizure disorder, bilateral renal angiomyolipomas, ventricular rhabdomyomas, choledochal cyst, epidermal inclusion cysts, skin tags, synchronous well-differentiated L-cell rectal neuroendocrine tumor and leiomyomatosis-like lymphangioleiomyomatosis of the rectum.

\section{Pancreatic NET}

Case report: 24 yo female with insulinoma and symptomatic hypoglycaemia and novel onset of seizures Case report: 23 yo male with insulinoma and recurrent seizures presented after 15 years of being seizure free Case report: 34 yo male with a pancreatic gastrinoma, presenting with reflux esophagitis and massive weight loss Case report: 28 yo male with insulinoma and behavioral changes characterised by episodes of agitation and, at other times, lethargy

Case report: 18 yo female with insulinoma with symptomatic hypoglycaemia.

Case report: 12 yo male with a malignant islet cell tumour

Case report: 43 yo male with insulinoma and episodes of Episodes of sweating and dizziness.

Case report: 6 yo male with a malignant islet cell tumour of pancreas

Case report: 39 yo male with a pancreatic islet cell tumor and lichenified hyperpigmented plagues (paraneoplastic process)

Case report: 31 yo male with TSC, multiple congenital subependymal nodules, bilateral cortical tubers, seizures and a malignant (metastatic) pancreatic neuroendocrine tumor.

Description of 5 patients with TSC (clinical diagnosis) and pancreatic tumors, 2 of them confirmed pancreatic neuroendocrine tumors, localized in the pancreatic tail ( 5 yo male with a $26 \mathrm{~mm}$ lesion and 12 yo male with a $10 \mathrm{~mm}$ lesion).

Case report: 35 yo female with TSC, adenoma sebaceum, shagreen patch and hypopigmented macules, bilateral renal angiomyolipomas and Hurthle cell adenoma. Multiple benign hamartomatous and inflammatory-type polyps in the cecum, sigmoid colon, and rectum. Pancreatic well-differentiated neuroendocrine tumor.

\section{Pheochromocytoma}

Case report: 29 yo female with a pleomorphic adrenal pheochromocytoma, recurrent fever and abdominal pain. Abdominal recurrence involving the spinal cord

\section{Carcinoid tumor}

Case report: 34 yo female with renal cysts and a bronchial carcinoid presenting by hemoptysis 2 years after diagnosis of "sporadic" lymphangiomyomatosis (LAM). On post-mortem examination LAM was observed in the lungs, mediastinal lymph nodes, kidneys and uterus. LOH for the TSC1 mutation observed in several tissues but not in the carcinoid tumor.
NA

NA

NA

NA

TSC2 (nonsense)

NA

A

NA

NA

NA

TSC2

TSC2 (nonsense)

TSC2 (1 bp ins)

NA

NA

TSC1 (2 bp del)

NA

TSC1 (nonsense)

${ }^{a}$ NA Not assessed

should be considered in the differential diagnosis [18]. Of note, glandular fundic polyps and tubular adenomatous polyps could be two different expressions of the same germline variation.
Finally, pancreatic neuroendocrine tumors (PanNET) are most commonly sporadic but have been reported previously in association with TSC and in other inherited cancer syndromes such as von Hippel-Lindau 
disease, Neurofibromatosis type 1 and Multiple endocrine neoplasia type 1 [45]. Most TSC patients diagnosed with NETs have pancreatic NETs, but NETs in other organs must be considered as part of the TSC phenotype. Recent studies have shown that most TSC patients with Pancreatic NETs have a germline pathogenic variant in TSC2 gene, as observed in our case. The multiple reports of NET in TSC patients and recent evidence for a pivotal role of TSC1 and TSC2 proteins in NET development and tumor's response to mTORC1 modulating interventions, point to a direct relationship between loss of function variants in TSC1 and TSC2 and NET suggesting that TSC clinical criteria should be modified to include NETs [46-48]. To our knowledge, there are no previous reports of tubular adenomatous polyposis in multiple segments of the GI tract in carriers of TSC2 germline pathogenic variants (Table 3). In a previous report describing molecular features of TSC patients, none of the probands reported GI tract polyposis [49].

In conclusion, there is currently no recommendation for GI polyp or PanNET screening, probably given the rarity of these findings, in TSC patients. Gastric and colorectal polyps and PanNETs are also not considered as phenotypic criteria for the clinical diagnosis of the syndrome. The patient described here, with confirmed molecular diagnosis of TSC underscores the importance of considering GI tract polyposis and NETs as part of the syndromic phenotype.

\section{Abbreviations}

TSC: Tuberous Sclerosis Complex; MRI: Magnetic resonance imaging; CT: Computed tomography; HE: Hematoxylin and eosin;

NET: Neuroendocrine tumor; PanNET: Neuroendocrine pancreatic tumor; IHC: Immunohistochemistry; Melan A: Melanoma antigen; HBM45: Melanosomal glycoprotein gp100 antigen; CGA: Chromogranin A antigen; Sinapto: Synaptophysin; LGR: Large gene rearrangements; FAP: Familial adenomatous polyposis; T1BD: TSC1 binding domain; GI: Gastrointestinal; FGPs: Gastric fundic polyps; GCR: Glucocorticoid receptor

\section{Acknowledgments}

We would like to thank the wife of the deceased patient for permitting publication of her husband's case report, Conselho Nacional de Desenvolvimento Científico e Tecnológico (CNPq) for financial support, and pathologists Elder Lersch and Carlos Bacci for organizational support.

\section{Authors' contributions}

L.B.R, D.K. and P.A-P collected data and wrote the manuscript. P.A-P, G.P., P.B and C.B.O.N treated the patient and interpreted the data. P.B. ordered diagnostic laparoscopy and colonoscopy and was the primary clinical oncologist of the case. G.P. was consulted for a second opinion and referred the patient for genetic evaluation. P.A-P was involved with conception of the report and acted as a supervisor. All the authors read and approved the final manuscript.

\section{Funding}

Not applicable.

\section{Availability of data and materials}

Not applicable.

Ethics approval and consent to participate Not applicable.

\section{Consent for publication}

The spouse of the patient described here, has provided written informed consent (for the) submission of this case report since the patient was already deceased. Consent to publish included the images in Figure(s) 1a, 1b, 1c, 1d, $1 \mathrm{e}, 1 \mathrm{f}, 2 \mathrm{a}$ and $2 \mathrm{~b}$.

\section{Competing interests}

The authors declare that they have no conflict of interest or financial disclosure.

\section{Author details \\ 'Laboratório de Medicina Genômica - Centro de Pesquisa Experimental - Hospital de Clinicas de Porto Alegre (HCPA), Porto Alegre, Rio Grande do Sul, Brazil. ${ }^{2}$ Programa de Pós-graduação em Genética e Biologia Molecular, Universidade Federal do Rio Grande do Sul (UFRGS), Porto Alegre, Rio Grande do Sul, Brazil. ${ }^{3}$ Hospital Mãe de Deus, Porto Alegre, Rio Grande do Sul, Brazil. ${ }^{4}$ Hospital São Lucas, Escola de Medicina da Pontifícia Católica do Rio Grande do Sul (PUCRS), Porto Alegre, Rio Grande do Sul, Brazil. ${ }^{5}$ Serviço de Genética Médica, Hospital de Clinicas de Porto Alegre (HCPA), Rua Ramiro Barcelos 2350, Porto Alegre, RS CEP: 90035-903, Brazil. ${ }^{6}$ Hospital São Vicente de Paulo, Passo Fundo, Rio Grande do Sul, Brazil.}

Received: 13 July 2020 Accepted: 1 October 2020

Published online: 23 November 2020

\section{References}

1. Northrup H, Krueger DA, Group ITSCC. Tuberous sclerosis complex diagnostic criteria update: recommendations of the 2012 linternational tuberous sclerosis complex consensus conference. Pediatr Neurol. 2013;49: 243-54. https://doi.org/10.1016/j.pediatrneurol.2013.08.001.

2. Henske EP, Jóźwiak S, Kingswood JC, Sampson JR, Thiele EA. Tuberous sclerosis complex. Nat Rev Dis Primers. 2016;2:1-18. https://doi.org/10.1038/ nrdp.2016.35.

3. Portocarrero LKL, Quental KN, Samorano LP, Oliveira ZNP, Rivitti-Machado MCDM. Tuberous sclerosis complex: review based on new diagnostic criteria. An Bras Dermatol. 2018:93(3):323-31.

4. Wataya-Kaneda M, Uemura M, Fujita K, Hirata H, Osuga K, Kagitani-Shimono $K$, et al. Tuberous sclerosis complex: recent advances in manifestations and therapy. Tuberous sclerosis complex Board of Osaka University Hospital. Int J Urol. 2017;24(9):681-91.

5. Sahin M, Henske EP, Manning BD, Ess KC, et al. Advances and future directions for tuberous sclerosis complex research: recommendations from the 2015 strategic planning conference. Pediatr Neurol. 2016;60:1-12. https://doi.org/10.1016/.jpediatrneurol.2016.03.015.

6. Rosset C, Netto COB, Prolla PA. TSC1 and TSC2 gene mutations and their implications for treatment in tuberous sclerosis complex: a review. Genetics and Mol Bio. 2017;40:69-79. https://doi.org/10.1590/1678-4685-GMB-20150321.

7. Randle SC. Tuberous sclerosis complex: a review. Pediatr. 2017;46:e166-71. https://doi.org/10.3928/19382359-20170320-01.

8. Cooper DN, Ball EV, Stenson PD, et al. The human gene mutation database (HGMD); 2020. http://www.hgmd.cf.ac.uk/ac/index.php. Accessed 11 February 2020.

9. Bundey S, Evans K. Tuberous sclerosis-a genetic study. J Neurol Neurosurg Psychiatry. 1969:32:591-603.

10. Buturovic S. Multiple colon polyposis. Med Arh. 2014;68:221-2. https://doi.org/10.5455/medarh.2014.68.221-222.

11. Groden J, Thliveris A, Samowitz W, Carlson M, et al. Identification and characterization of the familial adenomatous polyposis coli gene. Cell. 1991; 66:589-600. https://doi.org/10.1016/0092-8674(81)90021-0.

12. Plevová P. An update on inherited colon cancer and gastrointestinal polyposis. Klin Onkol. 2019;32:97-108. https://doi.org/10.14735/ amko2019597.

13. Huang J, Manning BD. The TSC1-TSC2 complex: a molecular switchboard controlling cell growth. Biochem J. 2008;412:179-90. https://doi.org/10. 1042/BJ20080281.

14. Hodges AK, Li S, Maynard J, et al. Pathological mutations in TSC1 and TSC2 disrupt the interaction between hamartin and tuberin. Hum Mol Genet. 2001;10:2899-905. https://doi.org/10.1093/hmg/10.25.2899. 
15. Jang MA, Hong SB, Lee $\mathrm{JH}$, et al. Identification of TSC1 and TSC2 mutations in Korean patients with tuberous sclerosis complex. Pediatr Neurol. 2012;46: 222-4. https://doi.org/10.1016/j.pediatrneurol.2012.02.002.

16. Priya TP, Dalal AB. Tuberous sclerosis: diagnosis and prenatal diagnosis by MLPA. Indian J Pediatr. 2012;79:1366-9. https://doi.org/10.1007/s12098-0110408-y.

17. Lee JS, Lim BC, Chae J-H, et al. Mutational analysis of pediatric patients with tuberous sclerosis complex in Korean: genotype and epilepsy. Epileptic Disord. 2014;16:449-55. https://doi.org/10.1684/epd.2014.0712.

18. Digoy GP, Tibayan F, Young H, Edelstein P. Adenocarcinoma of the rectum with associated colorectal adenomatous polyps in tuberous sclerosis: a case report. J Pediatr Surg. 2000;35:526-7. https://doi.org/10.1016/S00223468(00)90231-8.

19. Kim BK, Kim Yl, Kim WH. Hamartomatous gastric polyposis in a patient with tuberous sclerosis. J Korean Med Sci. 2000;15:467-70. https://doi.org/10. 3346/jkms.2000.15.4.467.

20. Santos L, Brcic I, Unterweger G, Riddell R, Langner C. Hamartomatous polyposis in tuberous sclerosis complex: case report and review of the literature. Pathol Res Pract. 2015;211:1025-9. https://doi.org/10.1016/j.prp. 2015.09.016

21. Hoffman WH, Perrin JC, Halac E, Gala RR, England BG. Acromegalic gigantism and tuberous sclerosis. J Pediatr. 1978;93:478-80. https://doi.org/ 10.1016/s0022-3476(78)81170-6.

22. Bloomgarden ZT, McLean GW, Rabin D. Autonomous Hyperprolactinemia in tuberous sclerosis. Arch Intern Med. 1981;141:1513-5. https://doi.org/10. 1001/archinte.1981.00340120121024.

23. Tigas S, Carroll PV, Jones R, Bingham E, et al. Simultaneous Cushing's disease and tuberous sclerosis; a potential role for TSC in pituitary ontogeny. Clin Endocrinol. 2005;63:694-5. https://doi.org/10.1111/j.13652265.2005.02374.x

24. Nandagopal R, Vortmeyer A, Oldfield EH, Keil MF, Stratakis CA. Cushing's syndrome due to a pituitary Corticotropinoma in a child with tuberous sclerosis: an association or a coincidence? Clin Endocrinol. 2007;67:639-41. https://doi.org/10.1111/j.1365-2265.2007.02941.x

25. Ilgren EB, Westmoreland D. Tuberous sclerosis: unusual associations in fou cases. J Clin Pathol. 1984;37:272-8. https://doi.org/10.1136/jcp.37.3.272.

26. Yin W, Zhu DM, Wang DS, Wang DX, Wu EH, Zhu XY. Parathyroid adenoma with primary hyperparathyroidism and tuberous sclerosis. A case report. Chin Med J. 1984;97:599-602.

27. Mortensen LS, Rungby J. Tuberous sclerosis and parathyroid adenoma. J Clin Pathol. 1991;44:961-2. https://doi.org/10.1136/jcp.44.11.961.

28. Kolin DL, Duan K, Ngan B, Gerstle JT, Krzyzanowska MK, Somers GR, et al. Expanding the Spectrum of colonic manifestations in tuberous sclerosis: Lcell neuroendocrine tumor arising in the background of rectal PEComa. Endocr Pathol. 2018;29:21-6. https://doi.org/10.1007/s12022-017-9497-0.

29. Gutman A, Leffkowitz M. Tuberous sclerosis associated with spontaneous Hypoglycaemia. Br Med J. 1959;2:1065-8. https://doi.org/10.1136/bmj.2.5159. 1065.

30. Davoren PM, Epstein MT. Insulinoma complicating tuberous sclerosis. J Neurol Neurosurg Psychiatry. 1992;55:1209. https://doi.org/10.1136/jnnp.55. 12.1209

31. Schwarzkopf G, Pfisterer J. Metastasizing Gastrinoma and tuberous sclerosis complex. Association or coincidence? Zentralbl Pathol. 1994:139:477-81.

32. Kim H, Kerr A, Morehouse $\mathrm{H}$. The association between tuberous sclerosis and Insulinoma. AJNR Am J Neuroradiol. 1995;16:1543-4.

33. Boubaddi NE, Imbert Y, Tissot B, Chapus JJ, et al. Secreting Insulinoma and Bourneville's tuberous sclerosis. Gastroenterol Clin Biol. 1997:21:343.

34. Verhoef S, Diemen-Steenvoorde R, Akkersdijk WL, Bax NM, et al. Malignant pancreatic tumour within the Spectrum of tuberous sclerosis complex in childhood. Eur J Pediatr. 1999;158:284-7. https://doi.org/10.1007/ s004310051073.

35. Eledrisi MS, Stuart CA, Alshanti M. Insulinoma in a patient with tuberous sclerosis: is there an association? Endocr Pract. 2002;8:109-12. https://doi. org/10.4158/EP.8.2.109.

36. Francalanci P, Diomedi-Camassei F, Purificato C, Santorelli FM, et al. Malignant pancreatic endocrine tumor in a child with tuberous sclerosis. Am J Surg Pathol. 2003;27:1386-9. https://doi.org/10.1097/00000478200310000-00012.

37. Merritt JL, Davis DMR, Pittelkow MR, Babovic-Vuksanovic. Extensive Acrochordons and pancreatic islet-cell tumors in tuberous sclerosis associated with TSC2 mutations. Am J Med Genet A. 2006;140:1669-72. https://doi.org/10.1002/ajmg.a.31351.

38. Díaz DD, Ibarrola C, Sanz RG, Hurtado BP, Tabares JS, Ruizdelgado FC. Neuroendocrine tumor of the pancreas in a patient with tuberous sclerosis: a case report and review of the literature. Int J Surg Pathol. 2012;20(4):3905. https://doi.org/10.1177/1066896911428735.

39. Koc G, Sugimoto S, Kuperman R, Kammen BF, Karakas SP. Pancreatic tumors in children and Young adults with tuberous sclerosis complex. Pediatr Radiol. 2017:47:39-45. https://doi.org/10.1007/s00247-016-3701-0.

40. Mortaji P, Morris KT, Samedi V, et al. Pancreatic neuroendocrine tumor in a patient with a TSC1 variant: case report and review of the literature. Familial Cancer. 2018;17:275-80. https://doi.org/10.1007/s10689-017-0029-3.

41. Stern J, Friesen A, Böweting R, Babaryka I. Multiple bilateral Angiomyolipomas of the kidneys in tuberous brain sclerosis in association with Pleomorphus Pheochromocytoma. Fortschr Med. 1982;100:1809-12.

42. Sato T, Seyama K, Kumasaka T, Fujii H, et al. A patient with TSC1 Germline mutation whose clinical phenotype was limited to Lymphangioleiomyomatosis. J Intern Med. 2004;256:166-73. https://doi.org/ 10.1111/j.1365-2796.2004.01356.x

43. Devroede G, Lemieux B, Massé S, Lamrche J, Herman OS. Colonic Hamartomas in tuberous sclerosis. Gastroenterol. 1988;94:182-8.

44. Wei J, Chiriboga L, Yee H, Mizuguchi M, et al. Altered cellular distribution of Tuberin and glucocorticoid receptor in sporadic Fundic gland polyps. Mod Pathol. 2002;15:862-9. https://doi.org/10.1097/01.MP.0000024146.29531.5B.

45. Guilmette JM, Nosé V. Neoplasms of the neuroendocrine pancreas: an update in the classification, definition, and molecular genetic advances. Adv Anat Pathol. 2019;26:13-30. https://doi.org/10.1097/PAP.0000000000000201.

46. Dworakowska D, Grossman AB. Are neuroendocrine tumours a feature of tuberous sclerosis? A systematic review. Endocr Relat Cancer. 2009;16:45-58. https://doi.org/10.1677/ERC-08-0142.

47. Jiao Y, Shi C, Edil BH, de Wilde RF, et al. DAXX/ATRX, MEN1, and mTOR pathway genes are frequently altered in pancreatic neuroendocrine tumors. Science. 2011:331:1199-203. https://doi.org/10.1126/science.1200609.

48. Capurso G, Festa S, Valente R, Piciucchi M, et al. Molecular pathology and genetics of pancreatic endocrine Tumours. J Mol Endocrinol. 2012:49:R3750. https://doi.org/10.1530/JME-12-0069.

49. Rosset C, Vairo F, Bandeira I, Correia R, et al. Molecular analysis of TSC1 and TSC2 genes and phenotypic correlations in Brazilian families with tuberous sclerosis. PLoS One. 2017;12:1-15. https://doi.org/10.1371/journal.pone. 0185713.

\section{Publisher's Note}

Springer Nature remains neutral with regard to jurisdictional claims in published maps and institutional affiliations.
Ready to submit your research? Choose BMC and benefit from:
- fast, convenient online submission
- thorough peer review by experienced researchers in your field
- rapid publication on acceptance
- support for research data, including large and complex data types
- gold Open Access which fosters wider collaboration and increased citations
- maximum visibility for your research: over $100 \mathrm{M}$ website views per year
At BMC, research is always in progress.
Learn more biomedcentral.com/submissions 